\title{
Morke skyer i horisonten - geologi i fremtiden
} Af geolog og kontorchef Jes Pedersen,
Vejle Amt

Et stigende antal geologer har fået beskæftigelse ved amterne. Den kommende kommunalreform vil betyde en specialisering og centralisering af de geologiske opgaver, så der må forventes færre nye geologjob og mindre synlighed afgeologien $\mathrm{i}$ fremtiden.

Da jeg i 1986 skiftede fra minebranchen og fik job i Vejle Amt, var vi 3 geologer, - en hydrogeolog, en råstofkortlægger og en jordforureningsgeolog. På det tidspunkt var der vel 3-4 opslag af danske stillinger om året. Så i det lys er der nærmest et sprudlende jobmarked i dag. Vi var i øvrigt ca. 20, der startede på studiet 1974.

\section{Fra 3 til 25 geologer på 18 år}

I dag er vi omkring 25 geologer i Vejle amt, der arbejder med et meget bredt arbejdsfelt fra våde enge, over stoftransport, havet og jordforurening til grundvandsbeskyttelse. De fleste af os har løbende skiftet lidt i arbejdsfeltet inden for amtet, så vi har fået bred indsigt. En spændende arbejdsplads. Det er også karakteristisk, at vi har meget forskellig specialebaggrund, men alligevel kan udføre et godt stykke arbejde.

Det, vi efterspørger, er den grundlæggende geologiske viden og den analytiske sans, der er trænet gennem studiet. Har man hertil nogle gode sociale kompetencer og snust lidt til arbejdsområdet, er det helt perfekt. Vi er omkring tre gange så mange geologer ansat, som der er rene geologopgaver til. Resten af tiden bruges på projektstyring, sagsbehandling, formidling etc., så der på den måde er skabt flere arbejdspladser.

En parallel udvikling har vi ikke set i kommunerne. Her er der gennem tiderne ansat en del biologer, men geologerne har nok været for specialiserede til, at der er blevet ansat ret mange.

\section{Øget markedsføring i samfundet}

Noget af det, vi har satset ret massivt på i amterne, er at markedsføre de geologiske arbejdsfelter, vi arbejder med. Dels gennem naturture, geologiske lokaliteter, men først og fremmest gennem deltagelse i mange aftenmøder med vandværker og ejere af forurenede grunde, hvor vi har fortalt om resultaterne af vores arbejde. Også pressen giver i dag en rigtigt god dækning af det geologiske område - primært selvfølgelig der, hvor det betyder noget for folks dagligdag gennem forurenet grundvand eller oprydninger i lokalområdet. Jeg vil mene, at geologien for alvor blev opdaget af pressen, da Vejle Amt kunne beskrive en alvorlig pesticidforurening fra DSB-arealerne $i$ Ejstrupholm. Vi optog de fleste af TV-indslagene, og sammenlagt blev der bragt nyhedsdækning på flere timer. Det er meget, når et indslag typisk varer 50 sekunder. I den tid opnåede vi også, at vi ikke længere som standard blev benævnt som biologer på rulleteksterne, idet titlen geolog blev opdaget afjournalisterne.

Senere har pressen fortalt rigtig mange gode historier om geologien i samfundets tjeneste. Jeg tror, det er den vej, vi skal i et langt sejt træk for at styrke interessen for geologi.

Styrket samarbejde med universitetet Med den styrkede indsats i amterne og hos rådgiverne qua de opgaver, der er løst i det regi, synes jeg også, der er slået hul i de tunge universitetsmure, så samfundet begynder at kigge ind, og forskerne kigger ud. Alt andet ville også være spild af skatteborgernes penge, for vi sidder hver især med unikke kompetencer.

To markante og formaliserede samarbejder er dels GeoFysikSamarbejdet mellem Aarhus Universitet og alle amterne om metodeudvikling samt SESAM, hvor de jyske amter og Fyns amt samarbejder med Exogen Laboratoriet på AU omkring opstilling af en sedimentstratigrafisk og geokemisk/petrologisk beskrivelse af morænerne og smeltevandsaflejringer, der huser og beskytter vores grundvand.

Vejle Amt har også sammen med andre aktører gennem nogle år undervist $i$ faget "Forvaltningsgeologi", hvor vi fortalte om geologens dagligdag som ansat i det offentlige eller ved en rådgiver. Hvad er grænseværdier, lovgivning, forureningsbedømmelse grundvandstransport etc. afsluttende med, at de studerende 2 og 2 lavede en rigtig undersøgelse af en forurenet grund med Vejle Amts borerig osv. Undervisere var amtsfolk og folk fra rådgiverside. Kurset var en god brobygger til "samfundet", men blev desværre stoppet af manglende bevillinger. Ærgerligt.
Fremtiden efter kommunalreformen Med kommunalreformen står vi nu over for en ny tid for det geologiske arbejdsmarked. Og det ser bestemt ikke godt ud.

Jordforurening bibeholdes ved regionerne, men for den ansatte geolog bliver det et meget snævert arbejdsfelt uden daglig sparring fra grundvandsgeologer, vandløbsbiologer, agronomer osv.

Langthovedparten af vidensopsamlingen bliver flyttet til staten, der skal overvåge miljøet, kortlægge grundvandets sårbarhed etc.. Går det som det plejer, vil staten centralisere disse opgaver på få kontorer, og værdierne, man bliver målt på, vil være artikelskrivning og videnskabelige indgange, fremfor om man laver gode løsninger til de lokale vandværker mv. Der vil opstå store kommunikationsproblemer, og jeg tror heller ikke, der bliver skabt så mange "spin-off" jobs for geologer i statsregi, da opgaverne antageligt bliver svært specialiserede.

Nogle vil sikkert også vælge at følge med over i kommunerne, hvor de vil lave sagsbehandling, men jeg tror, de vil komme til at savne kontakten med de lidt tungere geologopgaver. For rådgiverne kan det blive et problem med færre, men større kunder. Får man ikke et udbud, kan der være lang tid til næste udbudsrunde.

Er det så bare et indlæg fra en kritisk amtsgeolog. Ja, det er det måske, men jeg håber stærkt, at vi hen ad vejen igen kan få fokus på at "sælge vores fag til samfundet". For geologer vil der altid være brug for. 